\title{
Seed Quality Enhancement for Improving Planting Value of Fresh and Aged Seed Lots of Chickpea
}

Mukesh Kumar, Shiv K. Yadav, S. Pandey ${ }^{1}$, Sangita Yadav, R. Yadav², S.K. Lal

10.18805/LR-4441

\begin{abstract}
Background: Chickpea is the largest produced food legume in South Asia. It is mainly grown in dry or rainfed area, where patchy plant stand often results due to delayed and non-uniform emergence. Moreover, genotypes vary for seed germination and seedling vigour. Therefore, the study was undertaken to find most appropriate seed treatment for enhancement of planting value of desi and kabuli type chickpeas.

Methods: Study was conducted at ICAR-IARI, New Delhi with fresh, 2 and 4 years stored seed lots of desi (Pusa 2028) and kabuli (Pusa 1108) varieties. The lots were compared with untreated (control) for quality and vigour parameters after giving seed enhancement treatments (SET); osmopriming, halopriming, solid matrix priming (SMP), thiram and neem khali.

Result: Investigations revealed that SMP and thiram seed treatments significantly enhanced germination and field performance of fresh as well as aged seeds in these varieties. Effectiveness of treatments was found more pronounced in kabuli than desi type and thus confirmed the usefulness of SETs for poor vigour seeds. Results also showed that seed quality and vigour of both the types were significantly affected with time in storage. However, desi variety maintained satisfactory germination and field performance up to 2 years under ambient conditions of storage.
\end{abstract}

Key words: Chickpea, Seed enhancement treatments, Seed quality, Seed vigour, Storage.

\section{INTRODUCTION}

Legumes are plants belonging to the family Leguminosae also called as Fabaceae that produce seeds within a pod (Kouris-Blazos and Belski, 2016). Common food legumes used for human consumption include; field peas, chickpeas, broad beans, lentils, soybeans, lupines, lotus, sprouts, mung bean, green beans and peanuts. Chickpea/ Bengal gram/ garbanzos (Cicer arietinum L.) is the largest produced food legume in South Asia and the $3^{\text {rd }}$ largest produced food legume globally after common bean and field pea (Yorgancilar and Bilgicli, 2014). There are two type of chickpeas; desi and kabuli, grown in the world recognized visually by seed coat colour and seed size. Chickpea is grown in more than 50 countries with $89.7 \%$ production area in Asia alone. India is the largest chickpea producing country accounting for $75 \%$ of the global chickpea production. It is an important pulse crop in India sharing 29.7 and $45 \%$ of the total area and production of total pulses, respectively (Maurya and Kumar, 2018). Desi and kabuli chickpea seeds show large variability among genotypes in seed germination and seedling vigour. There are biotic and abiotic constraints like; Fusarium wilt, pod borer etc. and drought, salinity, temperature etc. that are still hampering chickpea production. Moreover, it is mainly grown in dry or rainfed area, where patchy plant stand often result from failure of crop to emerge quickly and uniformly. Additionally, five insects are reported to infest the chickpea in storage and cause losses up to 14\% (Sharma et al., 2013), but effect on quality could be more.

For sustainable production under uncertain/less favorable growing conditions, good-quality seed has a
Division of Seed Science and Technology, ICAR- Indian Agricultural Research Institute, New Delhi-110 012, India.

${ }^{1}$ Germplasm Conservation Division, ICAR-National Bureau of Plant Genetic Resources, New Delhi-110 012, India.

2Division of Genetics, ICAR- Indian Agricultural Research Institute, New Delhi-110 012, India.

Corresponding Author: Sangita Yadav, Division of Seed Science and Technology, ICAR-Indian Agricultural Research Institute, New Delhi-110 012, India. Email: sangitaydv@gmail.com

How to cite this article: Kumar, M., Yadav, S.K., Pandey, S., Yadav, S., Yadav, R., Lal, S.K., Seed Quality Enhancement for Improving Planting Value of Fresh and Aged Seed Lots of Chickpea. Legume Research. ():

Submitted: 13-05-2020 Accepted: 16-06-2020 Published: 10-11-2020

significant potential of increasing on-farm productivity and enhancing food security (Afzal, 2013). Low-vigour seeds can be improved using a variety of seed enhancement technologies that will thrive under small holder cultivation conditions and also improve the supply of good-quality seed in the local seed industry. A wide range of techniques are now used to help sowing seeds and to improve or protect seedling establishment and growth under the changing environments and seedbed constraints. Harris, et al. (1999) reported seed priming as one of the important practices which ensures rapid and uniform germination under adverse environmental conditions. Shinde and Hunje (2020) reported significant improvement in values of all quality and yield parameters of kabuli chickpea seeds primed with Sprint (Mancozeb 50\% + Carbendazim 25\% WS) @ 2g per kg of 
seed. The effect of seed treatment with powdered neem and neem oil formulations suppressed nematode population growth and increased grain yield significantly in chickpea. The beneficial effect of thiram treatment is attributed to its role in reducing the fungal infection, control of pre and post mortality (Solenke et al., 1997) on the germinating seeds. In view of the above, the study was undertaken to find most appropriate seed treatment for enhancement of planting value of desi and kabuli type chickpea.

\section{MATERIALS AND METHODS}

Two years old seed lots were taken from Division of Seed Science and Technology and four years old lots were collected from Pulse Laboratories, ICAR- Indian Agricultural Research Institute, New Delhi. Seeds selected for experiment were bold and free from any damage. The details of materials and methods adopted in the present investigation conducted at Division of Seed Science and Technology, ICAR-Indian Agricultural Research Institute, New Delhi are given below.

A total of five different treatments were compared with untreated control $\left(T_{1}\right)$. The treatment, $T_{2}$ i.e. Osmo- priming was done by polyethylene glycol (PEG8000) solution containing $25 \mathrm{~g}$ PEG dissolved in $100 \mathrm{ml}$ water. The eight replicate of 50 seeds placed in PEG saturated two layers of filter paper in petri plate for $48 \mathrm{hrs}$ at $20^{\circ} \mathrm{C}$. Similarly, treatment $\mathrm{T}_{3}$ i.e. halo-priming was done by taking 2 percent solution of $\mathrm{KNO}_{3}$ instead of PEG. The solid matrix priming (SMP) treatment $\mathrm{T}_{4}$ i.e. carried out by mixing seed, vermiculite and water in the ratio of $1: 2: 2.5$ and kept at $20^{\circ} \mathrm{C}$ for 6 and 8 hours in kabuli and desi types, respectively. Primed seeds were then fan dried at room temperature under shade till the seed moisture came down to initial levels. Fungicidal treatments; $T_{5}$ and $T_{6}$, were done with thiram @ $2 \mathrm{~g}$ per $\mathrm{kg}$ of seed and neem khali @ $10 \mathrm{~g}$ per kg of seed, respectively.

Seed germination was determined as per ISTA (2007), with minor modifications. Eight replicates of 50 seeds of each variety and each treatment were tested for germination. In this method, seed were placed between two layer of wet germination paper which was then rolled and wrapped in wax sheet and placed in walk-in-germinator in an upright position maintained at $20 \pm 1^{\circ} \mathrm{C}$ and $95 \% \mathrm{RH}$ for 8 days. On the day of final count i.e. $8^{\text {th }}$ day, evaluated for normal seedling, abnormal seedling, dead and hard seed. Germination percentage was calculated based on number of normal seedlings on final count.

The damaged, decayed and deformed seedlings which were not able to produce normal seedling were counted and considered as abnormal seedling, expressed in percentage.

Ten normal seedlings were taken at random from each replication and shoot and root lengths of each seedling were measured in centimeter. The mean value was taken for analysis.

Ten normal seedlings were taken at random from each replication for observing seedling length were dried in hot air oven maintained at $70 \pm 1^{\circ} \mathrm{C}$ for $48 \mathrm{hr}$ and cooled in desiccator. The mean value of seedling dry weight in $\mathrm{mg}$ was taken for analysis.

The vigour indices (I and II) were computed by adopting the method of Abdul Baki and Anderson (1973) by using following formula:

Vigour $\operatorname{lndex} \mathrm{I}=$

Germination (\%) X Total Seedling Length (cm)

Vigour Index II =

\section{Germination (\%) X Seedling Dry Weight (mg)}

Field emergence was estimated by sowing 100 seeds in 4 replications in the field. Observations were recorded on alternate day till $30^{\text {th }}$ day of sowing. The emergence was expressed as percentage of seedling emergence.

Five seedlings from each replication and treatments were randomly extracted from soil and washed of the debris and soil particles. Care was taken that no root is damaged, while removing 30 days old seedlings from the plot of field emergence studies. The excess water on the seedlings was wiped with blotter paper and seedlings were placed on the machine "WinRHIZO Pro" for image acquisition (Fig 1). Before analysis, the roots were first digitized with the scanner during 2014-15. The software was run to measure Root length, Surface area, Volume, Average diameter, Numbers of tips etc.
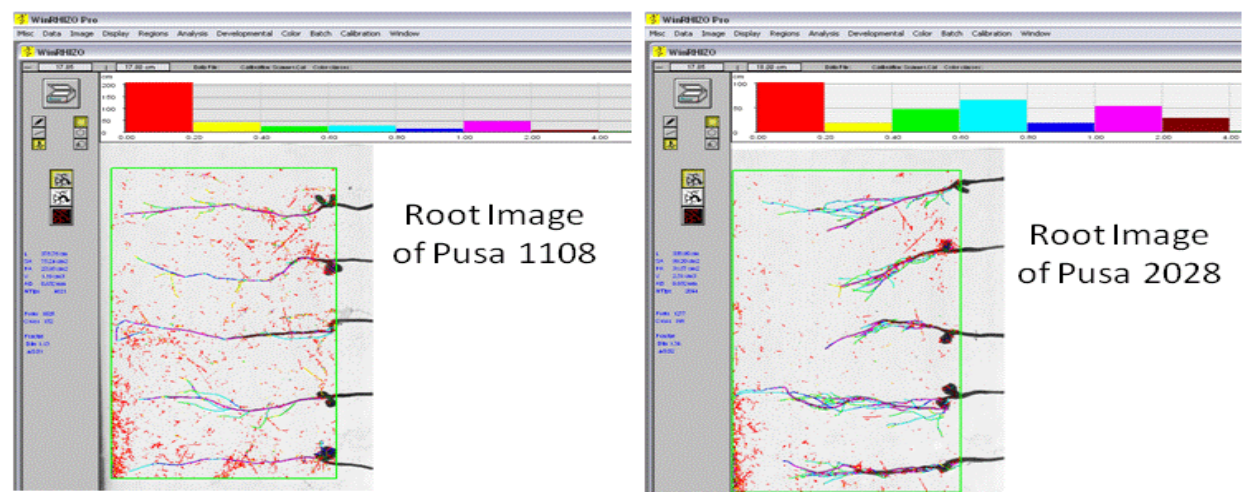

Fig 1: Analysis of digitized images of chickpea roots with WinRHIZO Pro. 


\section{Statistical analysis}

The data from laboratory experiment were collected by adopting complete randomized design (CRD), while data collected from field experiment were through randomized block design (RBD) as prescribed by Panse and Sukhatme (1985). The data were analyzed using the software SPSS10.0.

\section{RESULTS AND DISCUSSION}

The experiment was undertaken keeping in view two main objectives first to observe the loss in vigour of desi and kabuli chickpea stored under ambient condition and second to see effect of seed enhancement treatment on planting value. The germination percentage of fresh seed lots (Table 1) revealed that both desi and kabuli variety i.e. Pusa 2028 and Pusa 1108 had more than 90 percent germination. However, it was higher in desi type chickpea. This is largely because desi type is basically a semi tropic crop thus is

Table 1: Mean values of seed quality parameters of fresh seed lots of chickpea genotypes.

\begin{tabular}{lcc}
\hline Parameters & $\begin{array}{c}\text { Pusa 2028 } \\
\text { Desi }\end{array}$ & $\begin{array}{c}\text { Pusa 1108 } \\
\text { Kabuli }\end{array}$ \\
\hline Germination & 93.0 & 91.0 \\
Abnormal Seedling & 3.0 & 7.0 \\
Seedling Length & 21.5 & 17.5 \\
Seedling Dry Wt & 0.570 & 0.657 \\
Vigour Index I & 1999 & 1592 \\
Vigour Index II & 53.01 & 59.79 \\
Field Emergence & 91.0 & 88.0 \\
\hline
\end{tabular}

more suited to Indian conditions compared to kabuli types a temperate crop. In the two year old seed lot, loss of germination was more in kabuli type. The mean germination of Pusa 2028 and Pusa 1108 were 87 and 73, respectively (Table 2 and 3 ). Similar trend with respect to loss in germination was observed in four year old seed lots as presented in Table 4 and 5 . In the fresh seed lots, because of higher value of most of vigour parameters, the effect of seed enhancement treatment was not significant. But in the two year and four year old seed lots; SMP, thiram and neem khali improved the germination significantly. The comparative effectiveness of treatment on two types was more pronounced in kabuli type. Kabuli types suffer more loss of vigour and injury due to faster imbibitions of water and pathogenic incidence due to cracking in large seeded varieties (Yadav and Sharma, 2001).

The proportion of abnormal seedling in the fresh seed lot of kabuli type viz. Pusa 1108 was more than desi type viz. Pusa 2028. In storage, the number of abnormal seedling increased was much faster in kabuli lot. It was observed that in the fresh, two year old and four year old lot the number of abnormal seedling in kabuli were $7,11.33$ and 13.16 respectively, where as in desi type it were 3, 6 and 8.16, respectively. It was observed that SMP and thiram were among the two seed enhancement treatment which significantly reduced the number of abnormal seedling in both desi and kabuli type. Kabuli chickpea seeds treated with Sweet flag rhizome @ $10 \mathrm{~g} / \mathrm{kg}$, an alternative to chemicals, also reported to have maintained higher seed quality during storage (Shinde and Hunje, 2019).

Table 2: Effect of enhancement treatments on the performance of two year old seed of desi variety Pusa 2028 of chickpea.

\begin{tabular}{lccccccc}
\hline Treatments & $\begin{array}{c}\text { Germination } \\
(\%)\end{array}$ & $\begin{array}{c}\text { Abnormal } \\
\text { Seedling }(\%)\end{array}$ & $\begin{array}{c}\text { Seedling } \\
\text { Length }(\mathrm{cm})\end{array}$ & $\begin{array}{c}\text { Seedling } \\
\text { Dry Wt. (mg) }\end{array}$ & $\begin{array}{c}\text { Vigour } \\
\text { Index I }\end{array}$ & $\begin{array}{c}\text { Vigour } \\
\text { Index II }\end{array}$ & $\begin{array}{c}\text { Field } \\
\text { Emergence }(\%)\end{array}$ \\
\hline Control & 84.0 & 6.0 & 18.2 & 0.560 & 1528.8 & 47.0 & 81.0 \\
Osmopriming & 86.0 & 6.0 & 18.7 & 0.562 & 1608.2 & 48.3 & 82.0 \\
Halopriming & 87.0 & 7.0 & 18.7 & 0.561 & 1626.9 & 48.8 & 82.0 \\
SMP & 88.0 & 5.0 & 19.9 & 0.575 & 1751.2 & 50.6 & 92.0 \\
Thiram & 89.0 & 5.0 & 19.2 & 0.570 & 1708.8 & 50.7 & 89.0 \\
Neemkhali & 88.0 & 7.0 & 18.4 & 0.565 & 1619.2 & 49.7 & 84.0 \\
Mean & 87.0 & 6.0 & 18.9 & 0.565 & 1640.5 & 49.2 & 85.0 \\
CD $(p=0.05)$ & 3.0 & 0.2 & 0.7 & NS & 56.4 & 15.7 & 2.6 \\
\hline
\end{tabular}

Table 3: Effect of enhancement treatments on the performance of two year old seed of kabuli variety Pusa 1108 of chickpea.

\begin{tabular}{lccccccc}
\hline Treatments & $\begin{array}{c}\text { Germination } \\
(\%)\end{array}$ & $\begin{array}{c}\text { Abnormal } \\
\text { Seedling }(\%)\end{array}$ & $\begin{array}{c}\text { Seedling } \\
\text { Length }(\mathrm{cm})\end{array}$ & $\begin{array}{c}\text { Seedling } \\
\text { Dry Wt. (mg) }\end{array}$ & $\begin{array}{c}\text { Vigour } \\
\text { Index I }\end{array}$ & $\begin{array}{c}\text { Vigour } \\
\text { Index II }\end{array}$ & $\begin{array}{c}\text { Field } \\
\text { Emergence (\%) }\end{array}$ \\
\hline Control & 70.0 & 12.0 & 16.4 & 0.643 & 1148.0 & 45.01 & 36.0 \\
Osmopriming & 69.0 & 14.0 & 16.4 & 0.654 & 1131.6 & 45.13 & 31.0 \\
Halopriming & 69.0 & 13.0 & 16.2 & 0.651 & 1117.8 & 44.92 & 29.0 \\
SMP & 77.0 & 9.0 & 17.5 & 0.685 & 1347.5 & 52.75 & 56.0 \\
Thiram & 78.0 & 9.0 & 17.1 & 0.658 & 1333.8 & 51.32 & 49.0 \\
Neemkhali & 75.0 & 11.0 & 16.8 & 0.649 & 1260.0 & 48.68 & 44.0 \\
Mean & 73.0 & 11.3 & 16.7 & 0.656 & 1223.1 & 47.96 & 40.8 \\
CD $(p=0.05)$ & 2.3 & 0.4 & NS & NS & 38.0 & 13.99 & 1.5 \\
\hline
\end{tabular}


Seed Quality Enhancement for Improving Planting Value of Fresh and Aged Seed Lots of Chickpea

Table 4: Effect of enhancement treatments on the performance of four year old seed of desi variety Pusa 2028 of chickpea.

\begin{tabular}{lccccccc}
\hline Treatments & $\begin{array}{c}\text { Germination } \\
(\%)\end{array}$ & $\begin{array}{c}\text { Abnormal } \\
\text { Seedling }(\%)\end{array}$ & $\begin{array}{c}\text { Seedling } \\
\text { Length }(\mathrm{cm})\end{array}$ & $\begin{array}{c}\text { Seedling } \\
\text { Dry Wt. (mg) }\end{array}$ & $\begin{array}{c}\text { Vigour } \\
\text { Index I }\end{array}$ & $\begin{array}{c}\text { Vigour } \\
\text { Index II }\end{array}$ & $\begin{array}{c}\text { Field } \\
\text { Emergence (\%) }\end{array}$ \\
\hline Control & 81.0 & 8.0 & 16.5 & 0.502 & 1336.5 & 40.66 & 75.0 \\
Osmopriming & 85.0 & 9.0 & 16.5 & 0.542 & 1402.5 & 46.07 & 76.0 \\
Halopriming & 87.0 & 8.0 & 16.9 & 0.521 & 1470.3 & 45.33 & 83.0 \\
SMP & 87.0 & 8.0 & 17.0 & 0.544 & 1479.0 & 47.32 & 88.0 \\
Thiram & 87.0 & 7.0 & 17.2 & 0.522 & 1496.4 & 45.41 & 87.0 \\
Neemkhali & 84.0 & 9.0 & 16.2 & 0.516 & 1360.8 & 43.34 & 76.0 \\
Mean & 85.2 & 8.2 & 16.7 & 0.524 & 1424.2 & 44.69 & 80.8 \\
CD $(P=0.05)$ & 3.4 & 0.2 & 0.6 & 0.18 & 51.9 & 14.31 & 3.3 \\
\hline
\end{tabular}

Table 5: Effect of enhancement treatments on the performance of four year old seed of kabuli variety Pusa 1108 of chickpea.

\begin{tabular}{|c|c|c|c|c|c|c|c|}
\hline Treatments & $\begin{array}{c}\text { Germination } \\
(\%)\end{array}$ & $\begin{array}{c}\text { Abnormal } \\
\text { Seedling (\%) }\end{array}$ & $\begin{array}{c}\text { Seedling } \\
\text { Length }(\mathrm{cm})\end{array}$ & $\begin{array}{c}\text { Seedling } \\
\text { Dry Wt. (mg) }\end{array}$ & $\begin{array}{l}\text { Vigour } \\
\text { Index I }\end{array}$ & $\begin{array}{l}\text { Vigour } \\
\text { Index II }\end{array}$ & $\begin{array}{c}\text { Field } \\
\text { Emergence (\%) }\end{array}$ \\
\hline Control & 67.0 & 12.0 & 16.0 & 0.647 & 1072.0 & 43.35 & 13.0 \\
\hline Osmopriming & 69.0 & 15.0 & 16.1 & 0.660 & 1110.9 & 45.54 & 7.0 \\
\hline Halopriming & 69.0 & 13.0 & 16.4 & 0.650 & 1131.6 & 44.85 & 18.0 \\
\hline SMP & 68.0 & 12.0 & 17.1 & 0.679 & 1162.8 & 46.17 & 17.0 \\
\hline Thiram & 67.0 & 14.0 & 16.7 & 0.642 & 1118.9 & 43.01 & 24.0 \\
\hline Neemkhali & 64.0 & 13.0 & 15.7 & 0.648 & 1004.8 & 41.47 & 19.0 \\
\hline Mean & 67.3 & 13.2 & 16.3 & 0.654 & 1100.1 & 44.07 & 16.3 \\
\hline$C D(P=0.05)$ & 2.1 & 0.6 & 0.5 & NS & 31.4 & 15.97 & 0.8 \\
\hline
\end{tabular}

Generally, the standard germination of a seed lot does not give the actual estimate of field performance. So, there is need to have some reliable parameters, for evaluation of the seed quality. Moreover, decreased field emergence and uniformity is directly related with low seed vigour potential of a variety. It was observed that seed vigour index-I was higher in fresh seed lot compared with 2 and 4 year old seed lot. The SVI-I was more in desi type compared to kabuli type (1592) in fresh seed lot (Table 1). After two and four years of storage the SVI-I declined due to reduction in both germination percentage and seedling length. Similar trend was observed in SVI-II. The decline in SVI-II in two year and four year old seed lot in comparison to fresh lot was due to loss in germination and seedling dry weight. As the storage period was increased there was a decrease in root, shoot length and seedling vigour. This may be attributed to seed deterioration leading to loss of seed viability owing to depletion of food reserves and decline in biological activity of embryo due to fungal invasion, insect damage, fluctuating temperature and relative humidity. Similar results on decline in germination and other quality parameters due to seed treatments in storage were also reported by Morshed et al. (2014) in chickpea.

However, among the different priming treatments used, SMP and thiram were found significantly effective to maintain SVI-I and SVI-II compared to control in both desi and kabuli types. It could be because these act as protective agents against seed deterioration due to pest infestation, fungal invasion thereby preventing free radical damage as a result of which all the seed protectants have maintained seed viability satisfactorily for longer period of storage as against control. Low and medium vigour seed lots were found more responsive to priming treatments as reported earlier by other workers (Nagarajan et al., 2005; Lee and Kim, 2000).

Planting value is determined by the field emergence which ultimately is the indicator of seed vigour. The field emergence data of fresh seed lots revealed that desi variety viz. Pusa 2028 had more than 90 per cent field establishment. However, it was only 88 percent in kabuli variety Pusa 1108. This is largely because of high germination and seedling length in desi variety. In the two year old seed lot, effect of ageing was more pronounced in kabuli type. The mean field emergence in control of Pusa 2028 and Pusa 1108 were 81 and 36 , respectively. The differences in comparison to fresh seed lot were much widened at incremental rate in both desi and kabuli variety. With increased storage period of four year, the field emergence dropped to 75 and $13 \%$ in the field for Pusa 2028 and Pusa 1108, respectively. This could be due to initiation of pre-germination metabolic activities in seed during imbibition. Cantliffe (2003) reported that priming including solid matrix priming of seeds enhanced germination and increased seedling emergence uniformity under adverse conditions. Pandita et al. (2010) also suggest that solid matrix priming in combination with Trichoderma viride can be successfully used to improve seedling emergence and productivity of okra under low temperatures.

It was observed that after enhancement treatment significantly helped in narrowing the gap of field emergence value. The effect of SMP and thiram improved the field emergence very significantly which was followed by neem khali. The comparative effectiveness of treatment was more pronounced in kabuli type. The effect of osmo priming and 
Table 6: Electrical conductance of all seed lots of chickpea genotypes.

\begin{tabular}{lcccc}
\hline \multirow{2}{*}{ Type } & Variety & $\begin{array}{c}\text { Fresh } \\
\text { lot }\end{array}$ & $\begin{array}{c}\text { Two year } \\
\text { old lot }\end{array}$ & $\begin{array}{c}\text { Four year } \\
\text { old lot }\end{array}$ \\
\cline { 3 - 5 } & & 9.35 & 11.25 & 12.79 \\
Desi & Pusa 2028 & 9.35 & 18.26 & 20.59 \\
\hline
\end{tabular}

halopriming was not very much significant in increasing field establishment of chickpea. But it was observed that primed seed exhibits greater germination rate and faster and uniform field emergence. The evidence was in agreement with Basar et al. (2005) and Lin and Sung (2001). There was also differential treatment effect observed between desi and kabuli types. The desi type shows better response to treatments in respect of faster and uniform field emergence. The mean values of all root parameters; root length, surface area, volume etc. were found to be non significantly affected by the variety, treatment and their interactions and therefore values are not given. Total length of all roots was $307 \mathrm{~cm}$ and $414 \mathrm{~cm}$ in desi variety where as it was $305 \mathrm{~cm}$ and 440 $\mathrm{cm}$ in kabuli variety in control and SMP treated seedlings, respectively. Similar observations were recorded for all other parameters in differentially aged seed lots of both the varieties.

Conductivity test measure leakage of electrolytes from seed and can be used as a vigour test to predict field emergence. Electrical conductivity (EC) test which measures the leakage of electrolytes was also studied on all the lots of desi and kabuli chickpeas. The mean EC value of fresh lots $(9.35 \mu \mathrm{mhos} / \mathrm{cm} / \mathrm{g})$ of desi type was lower than value of $17.09 \mu \mathrm{mhos} / \mathrm{cm} / \mathrm{g}$ present in kabuli type. With increase in aging period to 2 and 4 years the EC value also increased significantly (Table 6 ). The differences were more pronounced in kabuli types. Degree of seed leakage during imbibitions is influenced by stage of seed maturation, degree of seed ageing and incidence of damage (Powell et al., 1987). One of the factors affecting storability of kabuli chickpea varieties is the presence of thin seed coat leading to damage to membranes resulting in the loss of semi permeability, thereby causing higher leakage of ions in aged seed. Increased membrane permeability resulting in an increased EC of seed leachate has been reported in different crops with ageing (Gnyandev, 2015; Singh and Dadlani, 2003).

\section{CONCLUSION}

Seed enhancement treatments were found more effective in seeds with less viability and poor vigour. Desi varieties of chickpeas could maintain the seed quality above IMSCS under ambient conditions of storage for 2 years, but kabuli type loses seed quality may be because of damaged thin seed coat. The solid matrix priming and seed treatments with thiram could be effectively used for improving the planting value of both types and aged seed lots of chickpeas.

\section{ACKNOWLEDGEMENT}

The authors are thankful to the Indian Council of Agricultural Research, New Delhi for providing required funds for smooth conduct of research work and Division of Seed Science and Technology, ICAR- Indian Agricultural Research Institute, New Delhi for providing the necessary facilities for the studies.

\section{REFERENCES}

Abdul-Baki, A.A. and Anderson, J.D. (1973). Vigour determination in soybean by multiple criteria. Crop Science. 10: 31-34.

Afzal, I. (2013). Need for public-private partnership in seed technology. Dawn, October 14, 2013.

Basar, S.M.A., Farooq, M. and Tabassum, R. (2005). Physiological and biochemical aspects of seed vigour enhancement treatments in fine rice (Oryza sativa L.). Seed Science and Technology. 33: 623-628.

Cantliffe, D.J. (2003). Seed enhancements. Acta Horticulturae. 607: 53-59.

Gnyandev, B.M., Kurdikeri, B., Salimath, P.M., Ravinder, K. and Kailashnath (2015). Influence of seed size on storage potential of chickpea varieties. International Journal of Agricultural Science and Research. 5(4): 189-194.

Harris, D., Joshi, A., Khan, P. A., Gothkar, P. and Sodhi, P. S. (1999). On-farm seed priming in semi-arid agriculture: development and evaluation in maize, rice and chickpea in India using participatory methods. Experimental Agriculture. 35: 15-29.

ISTA (2007). International Rules for Seed Testing, International Seed Testing Association, Basserdorf, Switzerland.

Kouris-Blazos, A. and Belski, R. (2016). Health benefits of legumes and pulses with a focus on Australian sweet lupines. Asian Pacific Journal of Clinical Nutrition. 21(1):1-17.

Lee, S.S. and Kim, J.H. (2000). Total sugars, a-amylase activity and germination after priming of normal and aged rice seeds. Korean Journal of Crop Science. 43: 157-160.

Lin J.M. and Sung J. M. (2001). Pre-sowing treatments for improving emergence of bitter gourd seedlings under optimal and sub-optimal temperatures. Seed Science and Technology. 29(1): 39-50.

Maurya, O. and Kumar, H. (2018). Growth of chickpea production in India. Journal of Pharmacognosy and Phytochemistry. 7(5): 1175-1177.

Morshed, M.G., Kashem, M.A., Hossain, I., Rafii, M.Y. and Latif, M.A. (2014). Effect of fungicides in controlling root rot (Fusarium solani) of chickpea. Life Science Journal. 11 (2): 99-102.

Nagarajan, S., Pandita, V.K., Joshi, D.K., Sinha, J.P. and Modi, B.S. (2005). Characterization of water status in primed seeds of tomato (Lycopersicon esculentum Mill.) by sorption properties and NMR relaxation times. Seed Science Research. 15: 99-111.

Pandita, V.K., Anand, A., Nagarajan, S., Seth, R. and Sinha, S.N. (2010). Solid matrix priming improves seed emergence and crop performance in okra. Seed Science and Technology. 38: 665-674.

Panse, V.G. and Sukhatme, P.V. (1985). Statistical Methods for Agricultural Workers, I.C.A.R. Publication, New Delhi. pp. 14-33. 
Powell, A.A., Yule, L.J ., Thornton, J .M. (1987). Influence of the aerated hydration seed treatment on the response of Brassica seed to storage. In: Proceedings of National Symposium on Stand Establishment, 5, Columbus: OARDC. pp.141-149.

Sharma, R., Devi, R., Sharma, R.K. and Singh, M. (2013). Incidence and extent of damage due to insect pests of stored chickpea (Cicer arietinum L.) in Haryana state, India. Legume Research-An International Journal. 36: 142-146.

Shinde, P. and Hunje R. (2020). Effect of seed priming on growth and seed yield in kabuli chickpea (Cicer arietinum L.) varieties. Legume Research-An International Journal. 43: 68-74.

Shinde, P. and Hunje, R. (2019). Influence of seed treatment with botanicals and chemicals on storability of kabuli chickpea
(Cicer arietinum L.) varieties. Legume Research-An International Journal. 42: 773-781.

Singh K.K. and Dadlani, M. (2003). Effect of packaging on vigour and viability of soybean seed during ambient storage. Seed Research. 31(1): 27-32.

Solenke, R.B., Kore, S.S. and Sudewad, S.M. (1997). Detection of soybean seed borne pathogens and effect of fungicides. Journal of Maharashtra Agricultural University. 22(2): 168-170.

Yadav, S.P. and Sharma, S.P. (2001). Seed coat cracking and its effect on seed quality characteristics in kabuligram (Cicer arietinum L.). Seed Research. 29(1): 7-12.

Yorgancilar, M. and Bilgicli, N. (2014). Chemical and nutritional changes in bitter and sweet lupine seeds (Lupinus albus L.) during bulgur production. Journal of Food Science and Technology. 51(7): 1384-1389. 